\title{
WORKSHOP PERANCANGAN DAN PELAKSANAAN KEGIATAN PRAKTIKUM BAGI GURU IPA DI KECAMATAN NEKAMESE
}

\section{Workshop on Design and Implementation of Practical Activities for Science Teachers in Nekamese District}

\section{Kadek Ayu Astiti}

Universitas Nusa Cendana,

Kupang, Nusa Tenggara Timur, Indonesia

email:

kadek.ayu@staf.undana.ac.id

\section{Kata Kunci:}

Alat Praktikum IPA Sederhana

Praktikum IPA Sederhana

Rancangan Kegiatan Praktikum

\section{Keywords:}

Simple Science Practice Tool

Simple Science Practice

Practical Design

\begin{abstract}
Abstrak
Program ini dilakukan berupa kegiatan workshop bagi guru-guru IPA di sekolah mitra dengan tujuan untuk mengatasi permasalahan yang dialami mitra yakni guru-guru IPA di SMP N 2 Nekamese dan SMP N 3 Nekamese khususnya dalam hal melaksanakan kegiatan praktikum. Berdasarkan permasalahan yang dialami, beberapa tahap yang dilakukan dalam kegiatan ini diantaranya: I) memberikan materi dasar IPA (fisika, kimia, biologi) untuk meningkatkan pemahaman konsep dasar IPA bagi guru-guru IPA di sekolah mitra, 2) Teori dan praktek pemanfaatan media KIT IPA (mekanika, hidrostatik dan panas, listrik dan magnet, optik), 3) teori dan praktek merancang kegiatan praktikum IPA sederhana, 4) teori dan praktek merancang alat praktikum IPA sederhana kemudian dilakukan pendampingan dalam melaksanakan kegiatan praktikum dalam proses pembelajaran dan terakhir tahap evaluasi. Hasil yang diperoleh setelah kegiatan ini dilaksanakan adalah adanya peningkatan pengetahuan guru akan konsep IPA secara terpadu, peningkatan pemahaman dan keterampilan guru dalam menggunakan KIT fisika, perancangan percobaan sederhana dan perancangan alat praktikum IPA sederhana. Peserta cukup antusias dalam mengikuti kegiatan ini terlihat dari semangat datang untuk mengikuti kegiatan, serta diskusi yang dinamis. Selama kegiatan berlangsung dan diskusi lanjut terdapat permasalahan lain yang dimiliki mitra yakni kurangnya kemampuan guru dalam pengembangan media pembelajaran berbasis IT. Hal ini dapat menjadi referensi untuk kegiatan mendatang sehingga dapat mewujudkan proses pembelajaran yang lebih variatif dan menyenangkan.
\end{abstract}

(C) 2019 The Authors. Published by Institute for Research and Community Services Universitas Muhammadiyah Palangkaraya. This is Open Access article under the CC-BY-SA License (http://creativecommons.org/licenses/by-sa/4.0/). DOI: https://doi.org/l0.33084/pengabdianmu.v4il.340.

\section{PENDAHULUAN}

IPA merupakan salah satu mata pelajaran yang terdapat pada jenjang sekolah menengah pertama. Mata pelajaran ini sangat berkaitan erat dengan kegiatan praktikum
(Millar, 2004). Beberapa alasan yang dikemukakan pakar pendidikan mengenai pentingnya kegiatan praktikum dalam pembelajaran IPA, yakni I) praktikum dapat membangkitkan motivasi belajar IPA. Praktikum 
memberi kesempatan kepada siswa untuk memenuhi dorongan rasa ingin tahu dan rasa ingin bisa. 2) praktikum mengembangkan keterampilan dasar bereksperimen. Kegiatan yang paling banyak dilakukan scientist adalah melakukan eksperimen untuk melakukan eksperimen diperlukan keterampilan dasar seperti mengamati, mengukur, menggunakan alat, mengestimasi dan menganalisis. Kegiatan praktikum di sekolah dapat membantu siswa untuk memiliki kemampuan dasar tersebut. 3) praktikum menjadi wahana belajar pendekatan ilmiah. Banyak para pakar pendidikan IPA meyakini bahwa tidak ada cara terbaik agar siswa belajar pendekatan ilmiah kecuali menjadikan mereka sebagai scientist sehingga praktikum sangat membantu untuk mencapai hal tersebut, 4) praktikum menunjang materi pelajaran (Syamsu, 20I7; Laursen et al., 2007).

Permasalahan utama yang menjadi kendala guru dalam melaksanakan pembelajaran IPA pada tingkat SMP adalah keahlian guru yang bukan berasal dari lulusan sarjana IPA namun berasal dari lulusan Fisika, kimia atau biologi bahkan ada juga guru yang berasal dari teknik (Septiana et al., 20I8). Sejalan dengan yang diungkapkan guru di SMP N 2 Nekamese yang mana di sekolah tersebut terdapat I orang lulusan sarjana fisika, I orang sarjana biologi dan I orang sarjana teknik yang harus mengajar mata pelajaran IPA, sementara di SMP N 3 Nekamese semua guru IPA merupakan guru yang berasal dari lulusan sarjana biologi. Hal ini tentunya menjadi kendala besar bagi guru untuk mengajarkan IPA secara terpadu sesuai tuntutan kurikulum baik KTSP maupun KI3, seperti contoh guru yang memiliki keahlian Biologi merasa kesulitan dalam mengajar materi Fisika maupun kimia, guru yang berasal dari Fisika kesulitan mengajar biologi dan kimia, demikian juga yang terjadi pada guru yang merupakan lulusan teknik.

Berdasarkan kondisi tersebut, beberapa masalah yang menjadi prioritas guru dalam melaksanakan pembelajaran IPA di sekolah adalah I) kurangnya pengetahuan guru terkait kegiatan praktikum yang dapat dilakukan, 2) kurangnya pengetahuan guru akan nama, fungsi, dan cara kerja alat praktikum yang ada di sekolah mereka sehingga guru masih bingung dalam melakukan kegiatan praktikum terutama pada penggunaan KIT fisika yang terdapat pada masing-masing sekolah mitra, 3) kurangnya kreativitas guru dalam melaksanakan praktikum-praktikum IPA sederhana, 4) kurangnya keterampilan guru dalam membuat alat praktikum IPA sederhana yang dapat digunakan untuk mengatasi keterbatasan alat praktikum yang ada di sekolah (Sunguya et al., 20I4). Berdasarkan uraian analisis situasi tersebut, maka perlu diupayakan suatu solusi pemecahan masalah yang ada di SMP N 2 Nekamese dan SMP N 3 Nekamese yang dapat meningkatkan pengetahuan dan keterampilan guru dalam melakukan kegiatan praktikum dalam proses pembelajaran IPA.

\section{METODOLOGI}

Solusi yang diusulkan untuk mengatasi permasalahan tersebut adalah dengan mengadakan program kemitraan masyarakat (PKM) Guru IPA di Kecamatan Nekamese melalui kegiatan workshop pengembangan kompetensi guru yang mana kegiatan ini di dalamnya mencakup

I. Berkoordinasi dengan pihak sekolah terkait waktu, tempat dan persiapan dalam melaksanakan program kemitraan masyarakat yang akan dilaksanakan.

2. melaksanakan kegiatan workshop perancangan dan pelaksanaan kegiatan praktikum bagi guru-guru IPA di SMP N 2 dan SMP N 3 Nekamese yang di dalamnya dibagi menjadi beberapa tahap yakni:

a. pemberian materi dasar IPA (fisika, kimia, biologi) untuk peningkatan pemahaman konsep dasar IPA bagi guru-guru IPA di sekolah mitra. Kegiatan ini dilakukan dengan pemberian materi terkait dengan konsep-konsep dasar IPA (fisika, biologi, kimia) sesuai dengan materi yang terdapat pada kurikulum tingkat SMP. Pemberian materi ini akan memberi dampak terjadinya 
sharing antara pemateri dengan para guru serta antarguru yang memiliki keahlian berbeda.

b. pemberian teori dan praktik pemanfaatan media KIT IPA (mekanika, hidrostatik dan panas, listrik dan magnet, optik) dalam melaksanakan kegiatan praktikum. Metode ini dilakukan dengan melatih guru-guru di sekolah mitra untuk memanfaatkan media KIT yang terdapat di sekolah mereka sehingga dapat berfungsi secara maksimal. Output dari kegiatan ini adalah peningkatan skill guru dalam menggunakan KIT dalam menggunakan praktikum.

c. pemberian teori dan praktek perancangan praktikum IPA sederhana. Kegiatan ini dilakukan untuk membantu guru melatih dan mengembangkan kreativitas dalam melaksanakan kegiatan praktikum IPA sederhana. Output dari kegiatan ini adalah rancangan praktikum IPA sederhana.

d. pemberian teori dan praktek perancangan alat praktikum IPA sederhana. Output dari kegiatan ini adalah rancangan alat praktikum IPA sederhana

3. Pendampingan dalam menggunakan media KIT IPA, rancangan kegiatan praktikum IPA sederhana yang telah disusun dalam kegiatan praktikum pada proses pembelajaran.

4. Mengevaluasi program yang sudah dilaksanakan pada PKM.

Program ini dilaksanakan selama empat bulan mulai dari tahap persiapan, pelaksanaan hingga evaluasi dan pembuatan laporan mulai tanggal 7 Mei hingga 7 September 2018.

\section{HASIL DAN PEMBAHASAN}

Hasil yang diperoleh melalui kegiatan ini adalah adanya peningkatan pengetahuan dan keterampilan guru baik menggunakan alat praktikum di sekolah (KIT) maupun merancang alat praktikum IPA sederhana dan merancang kegiatan praktikum IPA sederhana. Kegiatan ini dilakukan setiap hari sabtu mulai tanggal 28 Juli hingga 25 Agustus 2018 sebanyak lima kali. Peserta kegiatan merupakan guru-guru IPA di sekolah mitra. Program ini dirasakan memberikan manfaat yang sangat besar bagi peserta. Selama kegiatan berlangsung terlihat peserta cukup antusias mengikuti kegiatan. Selama proses berlangsungnya kegiatan peserta juga aktif bertanya kepada narasumber terkait dengan hal-hal yang mereka belum mengerti atau masalah yang selama ini dialami saat melaksanakan proses KBM.

Program ini sangat bermanfaat bagi guru di sekolah mitra, karena selama ini sangat minim adanya kegiatan pelatihan sejenis yang dapat membantu permasalahaan guru dalam proses pembelajaran khususnya pelaksanaan praktikum dalam pembelajaran IPA. Sebelumnya guruguru mengakui bahwasannya banyak materi yang belum dipahami karena latar belakang pendidikan bukan lulusan IPA yakni masih berasal dari lulusan pendidikan fisika, kimia, bologi bahkan teknik, serta mereka kurang termotivasi melakukan kegiatan praktikum karena banyak alat khususnya komponen KIT yang belum dipahami cara penggunaannya baik fungsi dan cara merangkai serta konsep yang terdapat di dalamnya. Apabila alat tidak ada, guru kurang kreatif dalam merancang praktikum sederhana bahkan merancang alat praktikum IPA sederhana. Padahal kegiatan praktikum memiliki kedudukan penting dalam pembelajaran IPA melalui praktikum siswa memiliki peluang untuk mengembangkan dan menerapkan keterampilan proses sains, sikap ilmiah dalam rangka memperoleh pengetahuannya (Saleh, 20I2). Berdasarkan hasil penelitian yang dilakukann oleh Balram (2017) diperoleh bahwa terdapat perbedaan hasil belajar siswa yang diajarkan dengan metode ceramah dibandingkan menggunakan metode praktikum. Pembelajaran dengan metode praktikum disertai feedback memberi pengaruh sebesar $47,4 \%$ yang tergolong tinggi terhadap hasil belajar siswa. 
Selama kegiatan berlangsung, guru diberikan motivasi untuk melakukan kegiatan praktikum di kelas dengan menunjukkan manfaat praktikum dalam proses pembelajaran. Kegiatan pertama diawali dengan memberikan konsep IPA terpadu sehingga meskipun guru bukan berasal dari IPA namun mulai memahami konsep pembelajaran IPA secara terpadu. Melalui sharing konsep dan referensi rancangan praktikum dan alat praktikum sederhana, guru mendapat tambahanan wawasan serta pendalaman materi baik fisika, kimia maupun biologi. Keterampilan guru juga dilatih dengan mengajak guru-guru peserta kegiatan ikut dalam menggunakan KIT serta ikut dalam merancang kegiatan dan alat praktikum IPA sederhana (Quillin \& Thomas, 2015). Beberapa perkembangan yang kami lihat diantaranya dari kurangnya pemahaman guru akan konsep IPA menjadi lebih luas pemahaman yang dimiliki, guru lebih termotivasi dalam melaksanakan kegiatan praktikum di kelas, bertambahnya kemampuan guru dalam merancang kegiatan dan alat praktikum sederhana.

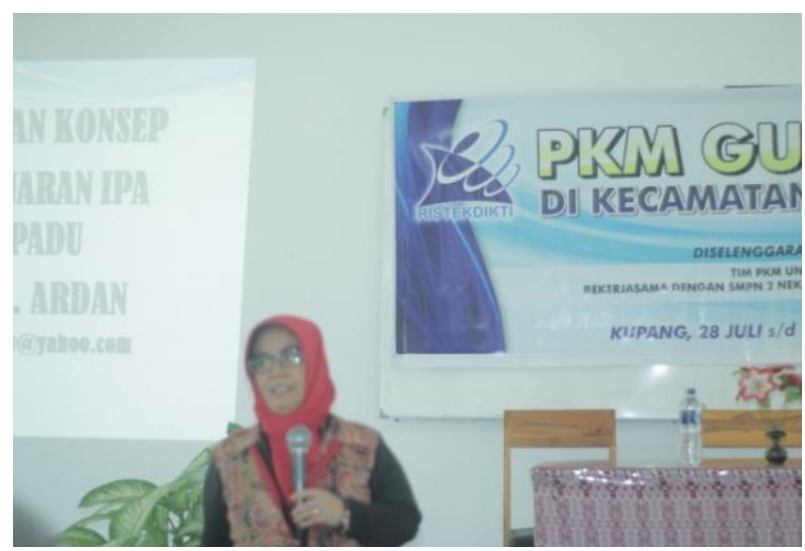

Gambar I. Pemberian materi minggu pertama oleh narasumber terkait konsep dasar pembelajaran IPA terpadu di SMP

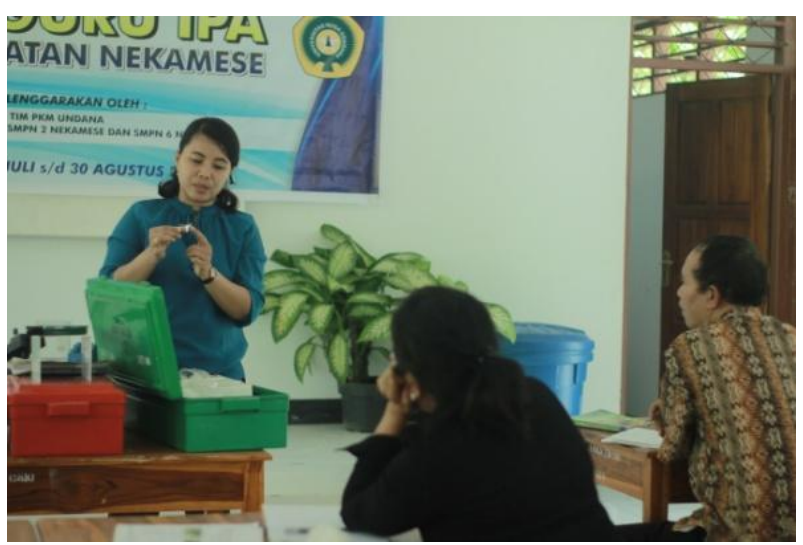

Gambar 2. Pemberian materi minggu kedua oleh narasumber terkait teori dan praktek penggunaan KIT fisika

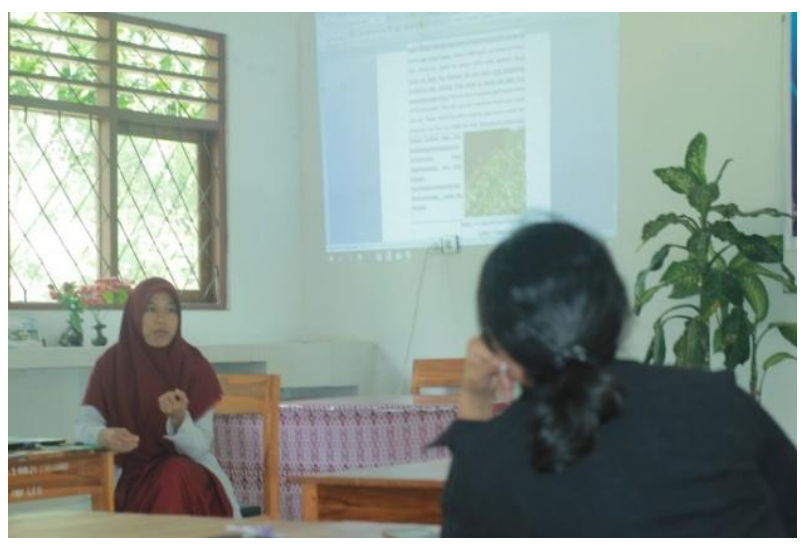

Gambar 3. Pemberian materi minggu ketiga oleh narasumber terkait teori dan praktek perancangan praktikum IPA sederhana

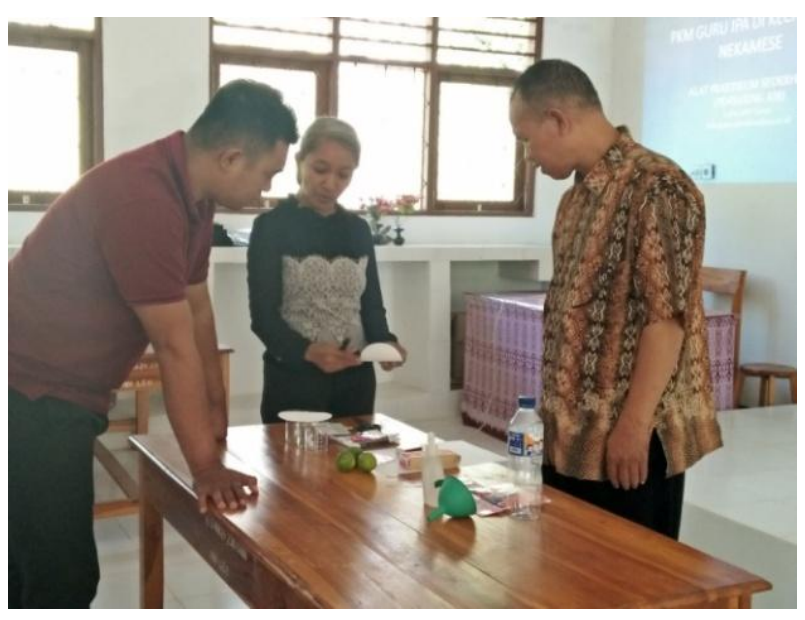

Gambar 4. Pemberian materi minggu keempat oleh narasumber terkait teori dan praktek perancangan alat praktikum IPA sederhana 


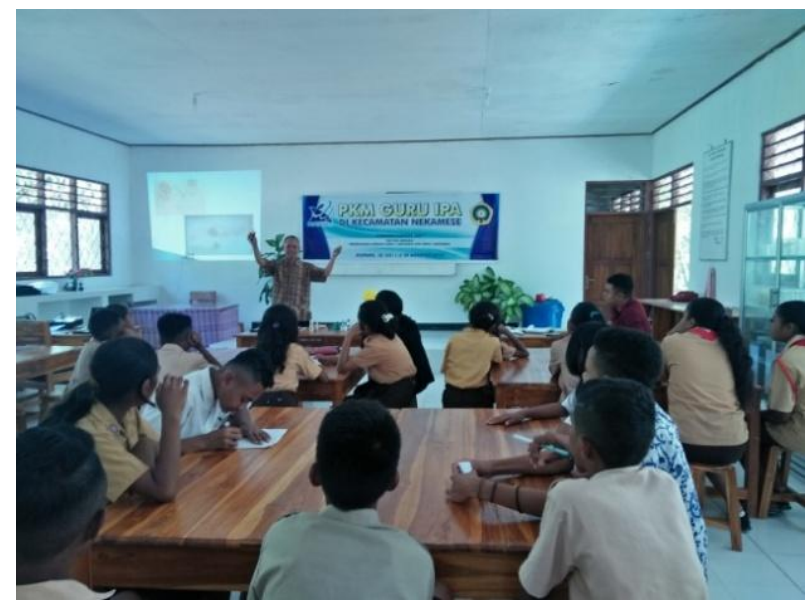

Gambar 5. Minggu kelima kegiatan pendampingan guru menerapkan praktikum IPA sederhana pada proses pembelajaran

\section{KESIMPULAN}

Program ini dapat membantu permasalahan yang tengah dihadapi guru-guru IPA di sekolah mitra dalam pelaksaan proses pembelajaran IPA di kelas serta penerapaan kegiatan praktikum dalam proses pembelajaran. Program ini berjalan lancar dan sekolah mitra cukup antusias dalam berperan aktif pada kegiatan ini. Peserta kegiatan juga terlihat antusias dan merasakan manfaat dari dilaksanakannya program ini. Program ini masih bisa dilanjutkan yakni tidak hanya sebatas perancangan desain alat praktikum IPA sederhana namun masuk ke pembuatan alat praktikum IPA sederhana. Selain itu juga perlu dilakukan kegiatan lanjutan sesuai tuntutan kurikulum yang berlaku yakni kurikululm 2013 yang mengarahkan proses pembelajaran IPA secara terpadu dengan mengadakan kegiatan workshop pembelajaran IPA terpadu.

\section{UCAPAN TERIMA KASIH}

Terima kasih kami ucapkan kepada semua pihak yang mendukung program ini yakni LP2M Undana selaku penyandang dana program, sekolah mitra yakni SMP N I Nekamese dan SMP N 3 Nekamese tempat pelaksanaan program ini berlangsung serta guru-guru IPA di sekolah mitra sebagai peserta kegiatan.

\section{REFERENSI}

Balram, R. 2017. Pengaruh metode praktikum disertai feedback terhadap hasil belajar dan respon siswa kelas $X$ pada materi larutan. Jurnal Pendidikan dan Pembelajaran. 6(6): I- 12 .

Laursen, S., Liston, C., Thiry, H., \& Graf, J. 2007. What Good Is a Scientist in the Classroom? Participant Outcomes and Program Design Features for a Short-Duration Science Outreach Intervention in K-12 Classrooms. CBE: Life Sciences Education. 6(I):49-64.

Millar, R. 2004. The role of practical work in the teaching and learning of science. York: University of York.

Saleh, M. 2012. Pembelajaran Kooperatif dengan Pendekatan Pendidikan Matematika Realistic (PMR). Jurnal Serambi Ilmu. I3(2):5 I-59.

Septiana, N., Rohmadi, M., Nasir, M., Nastiti, L.R., Usmiyatun, \& Riswanto. 2018. Kesulitan Guru IPA SMP/MTs Mengajarkan Ipa Terpadu di Kalimantan Tengah. Edu Sains: Jurnal Pendidikan Sains dan Matematika. 6(I): I-I I.

Sunguya, B.F., Hinthong, W., Jimba, M., \& Yasuoka, J. 2014. Interprofessional Education for Whom? - Challenges and Lessons Learned from Its Implementation in Developed Countries and Their Application to Developing Countries: A Systematic Review. PLoS One. 9(5):e96724.

Syamsu, F.D. 2017. Pengembangan Penuntun Praktikum IPA Berbasis Inkuiri Terbimbing untuk Siswa SMP Siswa Kelas VII Semester Genap. Bionatural: Jurnal Ilmiah Pendidikan Biologi. $4(2): 13-27$.

Quillin, K. \& Thomas, S. 20I5. Drawing-to-Learn: A Framework for Using Drawings to Promote Model-Based Reasoning in Biology. CBE: Life Sciences Education. 14(I):es2. 